\title{
The Broad Concept Of Joint Venture: Should It Have A Fixed Legal Meaning?
}

Maree Chetwin, (Email: maree.chetwin@canterbury.ac.nz), University of Canterbury, New Zealand

\begin{abstract}
What are joint ventures? What are the characteristics of a joint venture? Definitions and features of joint ventures will be considered in various jurisdictions with an emphasis on Australia and New Zealand. Should joint venture have a fixed legal meaning?
\end{abstract}

\section{INTRODUCTION}

$\varnothing$

oint ventures continue to increase in popularity but in some jurisdictions, mystery still surrounds the concept of joint venture and the obligations of a joint venturer. The structure of the joint venture can take a number of forms. It can be structured as a company and it becomes a separate entity, covered by statute. It is the unincorporated joint venture which generally poses the problems and questions. A major pitfall is the lack of a contract, or an agreement which is inadequate. The unincorporated joint venture can be categorised into those which are partnerships and those which are not. Joint venturers must be in agreement as to which structure is appropriate if they are to reach the consensus necessary for a contract, since very different legal and financial outcomes may result from the structure adopted. If there is a well drafted agreement it is straight forward as to the type of structure which governs the relationship and the rights and obligations of the parties. If the arrangement is a partnership then the relevant Partnership Act and law will apply. It is an unincorporated joint venture, which is not a partnership, which poses the problems.

The New Zealand Government ${ }^{1}$ has indicated that it is committed to working with the venture capital industry to develop a well-functioning, successful venture capital market in New Zealand. To achieve this end, a limited partnership regime will be introduced with the standard features of flow-through tax status, limited liability for investing partners and separate legal personality. This model, which reflects international best practice, will complement the venture capital tax reforms enacted to remove tax barriers to New Zealand companies attracting private equity and venture capital from institutional investors in specific countries. The new regime will also bring New Zealand's regulatory framework into line with international standards, and will provide venture capital investors with greater clarity and certainty. With the introduction of the new limited partnership regime in New Zealand, there will be a separate structure for joint ventures and it will be easier to determine that the parties are in a joint venture rather than a partnership.

However, this structure may not be utilised by all joint venturers and basic questions will remain. What is an unincorporated joint venture that is not a partnership? Can it be defined? Does it have specific characteristics? Is it more than a contract?

\section{WHAT IS AN UNINCORPORATED JOINT VENTURE?}

"Joint venture" is an ambiguous term and it has many meanings, which may depend on the context. ${ }^{2}$ There are many cases involving joint ventures and it is thus a growing area of the law. Duncan ${ }^{3}$ notes that the English,

1 See http://www.med.govt.nz/templates/ContentTopicSummary 26081.aspx $>$ at $28^{\text {th }}$ May 2007.

2 Z Shishido, Conflicts of Interests and Fiduciary Duties in the operation of a Joint venture, 1987, 39 Hastings L J 63, 66, the various approaches to a definition of a joint venture are discussed, including that of an economist and that used in the antitrust context.

3 W D Duncan, Joint Ventures Law in Australia, (2 ${ }^{\text {nd }}$ ed 2005), Australia, The Federation Press, 28. 
Canadian and New Zealand courts have moved in the direction of recognising joint ventures as constituting a distinct area of the law. There is no clear consensus amongst academic writers or the courts that this is the case. ${ }^{4}$ There is no universally accepted definition of a joint venture or agreement as to what constitutes a joint venture. In different jurisdictions there are different models. The term joint venture derives from early commercial relationships made in the $18^{\text {th }}$ and $19^{\text {th }}$ centuries in England where the parties were associated for a particular transaction. ${ }^{5}$ The Scottish joint venture is a particular species of partnership, which is confined to a particular transaction: ${ }^{6}$

There is a species of association in trade analogous to, or perhaps more correctly a variety of, partnership in which the partners use no firm or social name although they are associated in joint adventure or trade which is confined to a particular adventure, speculation, course of trade or voyage.

In the United States ${ }^{7}$ the joint venture is covered by Partnership law. However it is treated as a separate concept and there are clear differences from partnership. There was a prohibition of corporate partnership in the United States as it was considered that the officers and directors of a corporate partnership may not be able to carry out their responsibilities and that the corporate assets may be jeopardized in an ultra vires manner. ${ }^{8}$ The American concept of joint venture is not the same as that of Australia and New Zealand as it is closer to a partnership and partnership law applies.

The much-cited ${ }^{9}$ decision for our purposes is that of Mason, Brennan and Deane JJ in the leading Australasian authority United Dominions Corporation Ltd v Brian Pty Ltd. ${ }^{10}$ This provides insight into the broad nature and types of activity which can properly be described as a joint venture:

The term "joint venture" is not a technical one with a settled common law meaning. As a matter of ordinary language, it connotes an association of persons for the purpose of a particular trading, commercial, mining or other financial undertaking or endeavour with a view to mutual profit, with each participant usually (but not necessarily) contributing money, property or skill. Such a joint venture (or, under Scots' law, "adventure") will often be a partnership. The term is, however, apposite to refer to a joint undertaking or activity carried out through a medium other than a partnership; such as a company, a trust, an agency or joint ownership. The borderline between what can properly be described as a "joint venture" and what should more properly be seen as no more than a simple contractual relationship may on occasion be blurred. ${ }^{11}$

The mining and petroleum industries in Australia have successfully utilized unincorporated joint ventures despite the fact that they are not covered by statute and there is not a substantial body of judicial decisions. Ladbury $^{12}$ stresses that the mining joint venture is not a slavish adoption of the United States joint venture. Merralls

4 See B H McPherson J, Joint Ventures in P D Finn (ed 1987), Equity and Commercial Relationships, Sydney, Law Book Company.

5 See Halsbury's Laws of England, (4 ${ }^{\text {th }}$ ed) Vol 35, para 8.

6 Encyclopaedia of the Laws of Scotland (1931), Vol. II, s 67, 32 and Bell's Principles, s 392 cited by Samuels J in Brian Pty Ltd v United Dominion Corporation Ltd [1983] 1 NSWLR 490, 505; see also United Dominions Corporation Ltd v Brian Pty Ltd (1985) 60 ALR 741, 749 (Dawson J).

7 See 46 Am Jur 2d, Joint Ventures, s 2.

$8 \quad$ Williston on Contracts, ( $3^{\text {rd }}$ ed 1959), vol. 2, s 318 B, 598 et seq.

$9 \quad$ See eg Marr v Arabco Traders Ltd (1987) 1 NZBLC 102, 732; Commerce Commission v Fletcher Challenge Ltd [1989] 2 NZLR 554, 615; Aotearoa International Ltd v Paper Reclaim Ltd (19/03/04, Nicholson J, HC Auckland CP 117/01).

10 (1985) 157 CLR 1, 10 per Mason, Brennan and Deane JJ.

11 Encyclopaedia of the Laws of Scotland (1931), Vol II, s 67, 32 and Bell's Principles, s 392 cited by Samuels J in Brian Pty Ltd v United Dominions Corporation L td (1983)1 NSWLR 490 , 505; see also United Dominions Corporation Ltd v Brian Pty Ltd (1985) 60 ALR 741, 749 (Dawson J).

12 "Commentary" by R A Ladbury, in The Law of Public Company Finance, (eds Austin and Vann), Australia, Law Book Co, 1986, 37. 
${ }^{13}$ also emphasizes that the modern mining joint venture does not depend upon a priori notions derived from English, Scottish or American models.

"Joint venture' is undoubtedly an elastic term" "14, but it is not always clear that there is a joint venture. Is there any useful purpose in trying to define a joint venture? Ladbury ${ }^{15}$ states that he is not convinced there is a useful purpose but he does list three matters they have in common, namely: "(a) they are creatures of contract; (b) which create unincorporated associations; and (c) which are not partnerships." However, not all authorities and writers now say that there is always a contract.

\section{IS A CONTRACT ESSENTIAL?}

A difficulty in the context of the unincorporated joint venture is that there is not always a contract. If the parties have a contract, the unincorporated joint venture will be a contractual relationship and will be governed by traditional contract principles. There must be an intention to be immediately bound and there must be an agreement that spells out the essential terms before the contract will be binding. ${ }^{16}$

A precontractual agreement may take various forms such as, an agreement, a letter of comfort, a letter of intent, a confidentiality agreement. ${ }^{17}$ The legal effect of a letter of comfort illustrates the uncertain nature of such agreements, which will vary from jurisdiction to jurisdiction. ${ }^{18}$ A letter of comfort does not have a fixed legal meaning ${ }^{19}$ "Typically, a letter of comfort is provided by owners or directors to a prospective provider of finance to the company to induce the financier to advance funds to the company." ${ }^{20}$ In Chemco Leasing SpA v Rediffusion Plc ${ }^{21}$ Staughton J acknowledged that a letter of comfort was a "new creature". His Honour took the view that he was required to carry out the traditional task of ascertaining what common intentions should be ascribed to the parties from the two documents in question and the surrounding circumstances. Likewise, in Banque Brussels Lambert $v$ Australian National Industries Ltd ${ }^{22}$ the decision was reached on the basis of construction of the contract and the financier succeeded in recovering losses under a letter of comfort. However, the majority of decisions have been on the basis of intention to create legal relations. ${ }^{23}$ Burrows, Finn $\&$ Todd ${ }^{24}$ state that the cases should "be more readily considered in terms of the rules governing construction of a contract."

If the ordinary contract rules do not apply then questions arise as to other areas of liability. In some cases, the parties may never record their agreement in writing or the arrangement may fall apart without a concluded

13 J D Merralls QC, Mining and Petroleum Joint Ventures in Australia: Some Basic Legal Concepts, (1988) A L J 907.

14 Hadid $v$ Lenfest Communications Inc [1999] FCA 1798 at para 767.

15 R A Ladbury, Mining Joint Ventures, (1984) 12 A B L R 312, 339.

16 See Fletcher Challenge Energy Ltd v Electricity Corporation of New Zealand Ltd [2002] 2 NZLR 433, 444, per Blanchard J: The prerequisites to formation of a contract are therefore:

- (a) An intention to be immediately bound (at the point when the bargain is said to have been agreed); and

- (b) An agreement, express or found by implication, or the means of achieving an agreement (eg an arbitration clause), on every term which:

$\circ$ (i) was legally essential to the formation of such a bargain; or

- (ii) was regarded by the parties themselves as essential to their particular bargain.

17 See M K Omalu, Precontractual agreements in the energy and natural resources industries - legal implications and basis for liability (Civil law, Common law and Islamic law), J B L, 2000, Jul 303, 312.

18 Omalu above $303-331$.

19 See Banque Brussels Lambert SA v Australian National Industries Ltd (1989) 21 NSWLR 502, 520.

20 Burrows, Finn \& Todd, Law of Contract in New Zealand, ( $3^{\text {rd }}$ ed 2006), LexisNexis, Wellington, 150.

21 19/07/1985, Staughton J, Q B D, affd by the Court of Appeal [1987] FTLR 201.

22 (1989) 21 NSWLR 502.

23 See Kleinwort Benson Ltd v Malaysia Mining Corporation Berhad [1989] 1 All ER 785; Re Atlantic Computers plc (in administration); National Bank Ltd v Soden and another [1995] BCC 696; Bank of New Zealand v Ginivan [1991] 1 NZLR 178.

24 Burrows, Finn \& Todd, Law of Contract in New Zealand, ( $3^{\text {rd }}$ ed 2002), LexisNexis, Wellington, 150. 
contract. ${ }^{25}$ In many joint ventures the negotiation stage may involve complex issues and related expenses. If negotiations break down and the contract is not entered into there will be a cost to the injured party. Other areas of liability will be relevant, such as, whether the parties owe fiduciary duties to each other. It is for this reason that all joint ventures cannot be treated as creatures of contract. ${ }^{26}$

There is no single test that spells out fiduciary relationships. One approach is to consider if the parties demonstrate certain acknowledged indicia of a fiduciary relationship. Fiduciary duties is beyond the scope of this discussion, however the dicta in the recent Supreme Court case, Chirnside v Fay ${ }^{27}$ is informative. In that case, the Court was faced with a relationship where there was no formal agreement, or an express undertaking in relation to the joint venture. The Court held that it was a fiduciary relationship. Tipping $\mathrm{J}$ delivering the judgment of himself and Blanchard J stated: "The essence of a joint venture which is not yet contractual is that it is an arrangement or understanding between two or more parties that they will work together towards achieving a common objective...A joint venture will come into being once the parties have proceeded to the point where, pursuant to their arrangement or understanding, they are depending on each other to make progress towards the common objective. Each party is then proceeding on the basis that he or she is acting in the interests of all or both parties involved in the arrangement of understanding. A relationship of trust and confidence thereby arises; each party is entitled to expect from the others loyalty to the joint cause, loose as the formalities of the joint venture may still be." Gault $\mathrm{J}^{28}$ stated: "On the findings of fact of the trial Judge, they had embarked upon a joint enterprise on which they were working together in pursuit of a clear objective."

The warning of Blanchard J delivering the judgment of Elias CJ, Tipping, McGrath, Gault JJ and himself in the recent New Zealand case Paper Reclaim Ltd v Aotearoa International Ltd ${ }^{29}$ provides clear guidance. His Honour stated: "To style a contractual relationship as a joint venture may be apt to distract. It is a term to be applied with caution. When parties have formed a contract the correct approach is first to decide exactly what they have agreed upon." It was held that the courts below were too ready to label as a joint venture an arrangement that was no more than a contract of agency.

\section{CHARACTERISTICS}

Is it possible to identify the features of a joint venture?

Williston $^{30}$ lists factors, which must be present for a joint venture, which highlight the strong partnership basis:

(a) A contribution by the parties of money, property effort, knowledge, skill or other assets to a common undertaking;

(b) A joint property interest in the subject matter of the venture;

(c) A right of mutual control or management of the enterprise;

(d) Expectation of profit, or the presence of "adventure", as it is sometimes called;

(e) A right to participate in the profits;

(f) Most usually, limitation of the objective to a single undertaking or ad hoc enterprise.

Authorities in Australia and New Zealand have referred to American authorities ${ }^{31}$ despite the fact that the concept differs in America. However, this is not an unanimous approach ${ }^{32}$ as is indicative of the warning that the American writings "should perhaps be used with some care."

25 See eg Chirnside v Fay [2007] 1 NZLR 433.

26 See N Thompson, The nature of the joint venture, in W D Duncan (ed), Joint Ventures Law in Australia, (2 $2^{\text {nd }}$ ed 2005 ), The

Federation Press, Sydney, 7.

27 [2007] 1 NZLR 433, 461.

28 Ibid at 453.

29 [2007] NZSC 26 Para 31.

30 Williston on Contracts, $\left(3^{\text {rd }} \mathrm{ed}, 1959\right)$ at $563-5$. 
Joint control is a feature of the definition of a joint venture in the revised standard Interests in Joint Ventures (IAS 31) of the New Zealand Institute of Chartered Accountants. The New Zealand Standard (NZ IAS 31) is based on the International Accounting Standard (IAS 31) (revised 2000). For the International Accounting Standard Interests in Joint Ventures to apply there must be a valid binding contract. A joint venture is defined in paragraph 3 as "a contractual arrangement whereby two or more parties undertake an economic activity that is subject to joint control." For the purposes of the standard, joint control and a contractual arrangement are the two main characteristics of any joint venture as defined in paragraph 3:

Joint control is the contractually agreed sharing of control over an economic activity, and exists only when the strategic financial and operating decisions relating to the activity require the unanimous consent of the parties sharing control (the venturers). ${ }^{33}$

Control is the power to govern the financial and operating polices of an economic activity so as to obtain benefits from it. ${ }^{34}$

Paragraph 11 makes the point that the contractual arrangement should establish joint control and no one party should be in a position to have unilateral control. Paragraph 12 clarifies that one venturer may have operational control acting in accordance with the financial operating polices agreed by the venturers. If the operator has the power to govern the financial and operating polices, the arrangement is that of a subsidiary and not a joint venture.

In the New South Wales Court of Appeal in Brian Pty Ltd v United Dominions Corporation Ltd ${ }^{35}$ Samuels $\mathrm{J}$ adopted the American definition of Williston:

A joint venture is an association of persons, natural or corporate, who agree by contract to engage in some common, usually ad hoc undertaking for joint profit by combining their respective resources, without, however, forming a partnership in the legal sense (of creating that status) or corporation; their agreement also provides for a community of interest among the joint venturers each of whom is both principal and agent as to the others within the scope of the venture over which each venturer exercises some degree of control.[emphasis added]

On appeal, the High Court of Australia did not mention the control characteristic and defined a joint venture in ordinary language.

Joint control was listed as one of the recognizable and common characteristics of a joint venture in Gibson Motor Sport Merchandise Pty Ltd v Forbes.$^{36}$ Crennan $^{37}$ in that case made the point that it is always a question of

31 See N Thompson, The nature of the joint venture, in W D Duncan (ed), Joint Ventures Law in Australia, (2 $2^{\text {nd }}$ ed 2005), The Federation Press, Sydney, 33, and the discussion of Cummings v Lewis (unreported, FCA, Wilcox J, 2August 1991) it was held that there was a joint venture between Cummings, a famous Australian race-horse trainer and a firm of accountants to market a racehorse syndicate to taxation clients. For Wilcox J, the concept underlying the arrangement was "mutual but differing benefits to the two parties....the profits were entirely distinct and not shared." On Appeal, (1993)113 ALR 285, Cooper J, with whom Shepperd and Neaves JJ agreed, referred to the fact that although the relationship of joint venture is more fully defined in American jurisprudence and care must be taken in applying uncritically the American authorities, the concept in America requires a community of interest in the performance of the purpose of the parties to the contract. In support his Honour cited dicta from the judgment of Steinert J (with whom Beals, Robinson, Simpson and Jeffers JJ concurred) in Carboneau v Peterson 95 P 2d 1043 (1939), the Supreme Court of Washington. In the present case, there was no community of interest and no joint venture.

32 See McGechan J in Commerce Commission v Fletcher Challenge Ltd \& Ors (1989) 4 NZCLC 64, 973, 65, 026.

33 A venturer is also defined in para 3 as a party to a joint venture and has joint control over that venture.

34 More guidance on control and how to decide if control exists is provided in NZ IAS 27, paras 13 and 14.

35 (1985) 157 CLR 1, 10.

36 [2005] FCA 749, cited with approval in Thompson $v$ White \& Ors [2006] NSWCA 350, para 92.

37 [2005] FCA 749, para 92. 
fact whether there is a joint venture and that there were "various permutations and constellations" of the "recognizable and common characteristics". It followed that it was "not appropriate to attempt to isolate which characteristics would be both necessary and sufficient for the constitution of a joint venture agreement." Her Honour listed the recognizable and common characteristics as including:

1. Participants hold proprietary interests in the assets of the joint undertaking, often, but not necessarily, as tenants-in-common: see the abovementioned article of Mr Merralls QC. [J D Merralls QC., 'Mining and Petroleum Joint Ventures in Australia: Some Basic Legal Concepts' (1988) 62 ALJ 907],

2. Participants exercise joint control of the undertaking,

3. Participants contribute to the joint undertaking, not necessarily equally; such contributions may be disparate: Canny Gabriel Jackson Advertising Pty Ltd v Volume Sales (Finance) Pty Ltd (1974) 131CLR 321at 327; Television Broadcasters Limited v Ashton's Nominees Pty Ltd (No.1) (1979) 22 SASR 552,

4. Participants in the joint undertaking enjoy rights and assume obligations, which are often several, and calculated by reference to ownership of shares and/or contributions made,

5. Participants have a joint (or community of) interest in the performance of the undertaking's purpose: Cummings v Lewis (1993) 41 FCR 559 at 314/315 (per Cooper J),

6. Participants associate in the undertaking for mutual commercial gain which can be mutual profits.

The primary claim in this case was for breach of contract in relation to a V8 Supercar racing team. The proposals involving Ford, Mr Gibson, Mr Forbes and Mr Lowndes, a successful young professional, came together in around December 2000. In January 2001, the parties were in a position to publicly announce the establishment of a V8 Supercar racing team, to be known as the "Gibson Motor Sport", racing team for which Mr Lowndes was to race Ford cars. Mr Gibson had primary responsibility for the team's racing activities; Mr Watson conducted its merchandising activities; Mr Forbes controlled and operated the company that owned most of the team's main assets (through the second respondent, Racecar Preparation \& Management Pty Ltd, ('RPM'). The applicants alleged that the parties were contractually structured as a joint venture in which each party made some special contribution to the team's assets and opportunities. It was alleged there were a number of collateral contracts defining specific relationships between RPM and Mr Forbes on the one hand and each of Mr Gibson, Mr Watson and their related companies on the other. The applicants argued that they came within the broad definition given to the term 'joint venture' in United Dominions Corporation Ltd v Brian Pty Ltd. ${ }^{38}$

It was argued that conduct between 7 December 2000 and 26 February 2001 was conduct from which a joint venture agreement could be inferred. However, such conduct must be capable of providing all the essential elements of an express contract. In this case, the parties all had their own advisers, accountants and lawyers and a joint venture as was alleged would have required "what is sometimes called 'a suite of agreements". ${ }^{39}$ Crennan J took the view on the facts that there was no agreement on either of the dates contended for, for a joint undertaking for mutual commercial gain in a motor sport business.

In the Supreme Court of New South Wales case, Thompson $v$ White \& Ors ${ }^{40}$ Tobias JA referred to United Dominions Corporation Ltd and Gibson Motor Sport Merchandise Pty Ltd in deciding whether there was a joint venture:

the common characteristics of joint ventures identified by Crennan J cannot be said to be either severally or jointly both necessary and sufficient to constitute a joint venture agreement, it being a question of fact whether any

$38 \quad$ (1985)157 CLR 1, 10.

39 Coal Cliff Collieries Pty Ltd v Sijehama Pty Ltd (1991) 24 NSWLR 1, 20 per Kirby J, which Crennan J stated was apt for the facts here.

40 [2006] NSWCA 350. 
particular undertaking constitutes a joint undertaking for mutual commercial gain .... the ordinary rules of contract relating to whether the parties intend to enter into a contractual relationship apply.. ${ }^{4}$

The characteristics of a partnership are not a prerequisite to satisfying the definition. In Dollar Land (Cumbernauld) Ltd v CIN Properties Ltd ${ }^{42}$ it was alleged for a sublessee that the nature of the arrangement between it and the head lessee referable to development land in Cumbernauld was such as to make them partners ${ }^{43}$ in relation to its proposed development. Lord Coulsfield rejected an allegation of partnership:

... it is undoubtedly true that there is no one provision or feature which can be said to be absolutely necessary to the existence of a partnership, so that the absence of that feature inevitably negates the existence of a partnership.

There is no consensus on the characteristics of a joint venture and even if there was it would be of little assistance in satisfying a definition as the characteristics are not the same as the prerequisites. What is clear is that the venturers must have "embarked upon a joint enterprise on which they were working together in pursuit of a clear objective." $" 44$

\section{DISTINCTIONS}

\section{Joint Venture Or Partnership?}

In many cases, it will be necessary to decide whether what the parties have agreed to amounts to a partnership. Lindley \& Banks ${ }^{45}$ note that although partnerships and joint ventures have a number of common characteristics, the courts have adopted an inconsistent attitude to joint ventures. Sometimes the terms are used interchangeably and in others the joint venture is seen as a relationship quite separate and distinct from partnership. It is recognised that all partnerships involve a joint venture but the reverse is not the case. If there is a partnership then the relevant Partnership Act and law will apply. However, it is not always clear that there is a partnership.

The New Zealand Partnership Act 1908 is based on the United Kingdom Partnership Act 1890. Section 4 (1) of the New Zealand act defines a partnership: "Partnership is the relation which subsists between persons carrying on business in common with a view to profit." Whether any arrangement falls within the definition can only be determined by looking at the arrangement as a whole to determine the intention of the parties. The problem of distinguishing between a partnership and a joint venture has been central to many cases and in particular in United Dominions Corporation Ltd v Brian Pty Ltd. ${ }^{46}$

The above definition can be broken down into three distinct parts: (1) the business (2) which is carried on and (3) with a "view to profit." The Act ${ }^{47}$ defines "business" as including "every trade, occupation, or profession". To satisfy the first part of the definition the parties according to Lord Millett in Khan v Miah ${ }^{48}$ must have "done enough to be found to have commenced the joint enterprise in which they had agreed to engage." It does not negative a partnership if actual trading has not commenced. In that case the parties intended to open a restaurant and purchased premises and took other steps to facilitate its proposed operation. However, the restaurant never opened. The House of Lords held that there was a partnership business.

\footnotetext{
41 Ibid at para 94-96.

42 (1996) SLT 186, 195.

43 The Act of 1890 applies in Scotland.

44 Chirnside v Fay [2007] 1 NZLR 433, 442 per Gault J.

45 Lindley and Banks on Partnership, ed R C I'Anson Banks (18 ${ }^{\text {th }}$ ed 2002), London, Sweet \& Maxwell, para 5. 07

46 (1985)157 CLR 1, 10.

47 Section 2 Partnership Act 1908.

48 [2001] 1 All ER 20, 24-25.
} 
In the High Court, Fay $v$ Chirnside ${ }^{49}$ William Young $\mathrm{J}$ had held that the parties were joint venturers and characterised the relationship in legal terms. His Honour considered much of what Lord Millett said was applicable and adopted Khan's case. His Honour's view was that the parties "had performed enough to be fairly engaged in a joint venture ${ }^{, 50}$ but they were not partners in the legal sense. On appeal, the Supreme Court ${ }^{51}$ took the view that the "joint venture will come into being once the parties have proceeded to the point where, pursuant to their arrangement or understanding, they are depending on each other to make progress towards the common objective." Whether or not the venturers have performed enough will depend on the facts of each case.

A number of joint ventures are formed for one off arrangements but that in itself does not mean that there is not a partnership. ${ }^{52}$ A "business" can exist even for a single undertaking of short duration. The words "carrying on" do not mean that there must be repetition. This aspect was discussed by Dawson J in United Dominions Corporation $L t d .^{53}$

Whilst the phrase "carrying on a business" contains an element of continuity or repetition in contrast with an isolated transaction which is not to be repeated, the decision of this Court in Canny Gabriel Castle Jackson Advertising Pty. Ltd v. Volume Sales (Finance) Pty. Ltd (1974) 131CLR 321 suggests that the emphasis which will be placed upon continuity may not be heavy.

In November 2003, the Law Commission and the Scottish Law Commission published a report on partnership law reform. ${ }^{54}$ One of the recommendations in respect of general partnership law was that the definition should be changed to "an association formed when two or more persons start to carry on a business together under a partnership agreement." This would preserve the decision in Khan's case, but, it does not make the definition any more straight forward as it would be difficult to determine what constitutes "start to carry on a business." However, the government decided not to take forward the recommendations in respect of general partnership law reform.

A long-standing point of contention that the provision for participation in profits still remains necessary to the existence of a contract of partnership was resolved by the English Court of Appeal in M Young Legal Associates $v$ Zahid. ${ }^{55}$ Wilson L J. was not persuaded that it was suggested by the Lord Ordinary, Lord Coulsfield in Dollar Land (Cumbernauld) Ltd v CIN Properties Ltd ${ }^{56}$ that the absence of the three features: "a sharing of profits and losses and mutual agency are typical of partnerships," would always negative partnership, rather that such was its effect in that case. Wilson LJ referred to other authorities including Stekel $v$ Ellice $^{57}$ and agreed with the lower court that the participation in profits is not necessary to satisfy the definition.

Hughes LJ agreed and noted that the definition section referred to the making of profit as an aim, but that it studiously abstained from reference to any necessity that it be shared.

The degree of integration was utilised as the difference between a partnership and a joint venture in the unreported decision, Spree Engineering and Testing Limited v. O'Rourke Civil and Structural Engineering

\footnotetext{
49 20/12/02, William Young J, HC Dunedin, CP 36/01.

50 20/12/02, William Young J, HC Dunedin, CP 36/01, para 49.

51 [2007] 1 NZLR 433, 463.

$52 \quad$ See eg Gallagher v Schulz (1988) 2 NZBLC 103,196, where the defendant, a property developer and builder was to build two flats on the plaintiff's land and the parties would share the resulting profits. The parties were held to be in business for the purposes of the definition.

53 (1985) 157 CLR 1.

54 (Law Com No 283; Scot Law Com No 192).

55 [2006] EWCA Civ 613, para 28.

56 (1996) SLT 186, 195.

57 [1973] 1 WLR 191.
} 
Limited. ${ }^{58}$ In that case, the companies carried out their own part of the work independently and the parties had specifically agreed provisions which avoided the degree of integration necessary for a partnership. On the facts, the court concluded that the joint venture between the two parties did not involve a partnership because they specifically agreed provisions which avoided the degree of integration necessary to found a partnership. The court's distinction was as follows:

An integrated joint venture generally satisfies (the partnership) test of "the relation which subsists between persons carrying on business in common with a view to profit." On the other hand, a non-integrated joint venture generally falls to be treated simply as an unincorporated association since the participants generally share no more than gross payments received.

\section{FORM V SUBSTANCE}

What is important is the substance of a relationship not the labelling or terminology used. Labelling by the parties is not conclusive of the arrangement. ${ }^{59}$

"In the end the matter is one of substance and intention." ${ }^{, 00}$ This was evident in Canny Gabriel Castle Jackson Advertising Pty Ltd v Volume Sales (Finance) Pty Ltd ${ }^{61}$ Fourth Media Management Pty Ltd, where a promoter had contracts with for the appearances of Cilla Black and Elton John in Australia. Volume Sales (Finance) Pty Ltd agreed to finance the contracts. The contract stated in clause 1 that in consideration of the advance of $\$ 70,000$ and further sums, Fourth Media agreed to assign to Volume Sales "a one half interest in the above recited contracts and to perform the said contracts as a joint venture". The High Court of Australia ${ }^{62}$ held that Volume Sales and Fourth Media were partners in the joint undertaking established by the agreement. The contract had all the indicia of a partnership except that it did not describe the parties as partners and did not provide expressly for the sharing of losses, although it did so impliedly. In United Dominions Corporation Ltd v Brian Pty Ltd ${ }^{63}$, the agreement between United Dominions Corporation, Brian Pty Ltd and Security Project Limited ("SPL") in the development project was described as a joint venture. However, despite the description, in substance it was a partnership.

In Whywait Pty Ltd \& Mays v Davison ${ }^{64}$ Supreme Court of Queensland - the Court of Appeal, Macrossan CJ, Pincus and McPherson JJ were faced with the same issue. The parties, Mr Cheers and the Davisons agreed to build certain townhouses. In the course of carrying out the building work, the appellant, Whywait Pty Ltd carried out certain plumbing work and sued for monies owing for work done and material supplied at the two building sites. There were references in the written partnership agreement itself, to "joint venture". Clause 5 of the written agreement referred to the Davisons receiving interest at 20 per cent on moneys advanced to the "joint venture"; $c 16$ (b) referred to Cheers engaging a builder to construct the four townhouses for a fee approved by the "joint venture

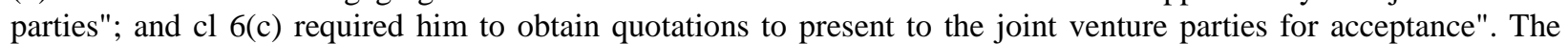
Court noted references to "joint venture" in the agreement itself and in oral evidence or correspondence and stated that they were essentially neutral. As every partnership involved a joint venture, to speak of a partnership in such terms did not resolve the problem. The Court looked at the definition of partnership and considered what was critical was the relation and the element of "mutual confidence that the partners will engage in some particular kind of

58 May 18, 1999 (NLC 299058403), cited by Girvan L J in Sweeney v Lagan Developments Ltd [2007] NICA 11, para 13; referred to in Lindley and Banks on Partnership ed R C I'Anson Banks (18 ${ }^{\text {th }}$ ed 2002), London, Sweet \& Maxwell, para 5.07 .

59 In Gibson Motor Sport Merchandise Pty Ltd v Forbes [2005] FCA 749 Crennan J noted that the applicants relied on a single instance use of the word 'partner' and a single instance of use of the word 'venture' by Mr Forbes in certain documents as evidencing a joint venture agreement: Such isolated uses by a non-lawyer cannot bear on the legal consequences of the facts.

60 Commerce Commission v Fletcher Challenge Ltd \& Ors (1989) 4 NZCLC 64,973, 65,028 per McGechan J.

61 (1974) 131 CLR 321.

62 McTiernan, Menzies and Mason JJ.

63 (1985) 157 CLR 1.

64 [1996] QCA 178. 
activity or transaction for the joint advantage only". ${ }^{65}$ The same mutual confidence is not present in a joint venture. Here, the parties, who on the facts had agreed to conduct a business of building the townhouses in common for profit, were held to be in a partnership.

\section{The Product V Profit Distinction}

In Australia many of the joint ventures are mining and petroleum joint ventures. A distinction that has been emphasized is that joint ventures differ from partnerships in that they involve a commercial activity where separate entities combine their resources and skills to produce or share a product. For example, the entities in a fishing venture may contract to share an agreed portion of their catch.

This distinction derives from United Dominions Corporation Ltd v Brian Pty Ltd ${ }^{66}$, where Dawson J, in agreeing with the majority, stated:

... [T]he important distinction between a partnership and a joint venture is, for practical purposes, the distinction between an association of persons who engage in a common undertaking for profit and an association of those who do so in order to generate a product to be shared among the participants. Enterprises of the latter kind are common enough in the exploration for and exploitation of mineral resources and the feature, which is most likely to distinguish them from partnerships is the sharing of product rather than profit.

His Honour did not find it necessary to pursue the distinction on the facts of the case. The profit v product distinction is not without its critics. One such critic, McPherson ${ }^{67}$ cites the early Australian authority Holderness $v$ Shackels ${ }^{68}$ to dispute the distinction. In Holderness, three part-owners of a whaling ship shared the whale blubber of an adventure. Tenterden CJ treated the joint venturers as partners.

Dawson J refers to "the exploration for and exploitation of mineral resources" and clearly it is feasible to take product from such ventures. More recently, Edmonds J (dissenting) in the Federal Court case, Seven Network (Operations) Ltd \& Anor v TCN Channel Nine Pty \& Ors, ${ }^{69}$ cited Dawson J's distinction stating that: "[i]t has long been recognized that one of the basic features of a joint venture is that the participants receive the fruits of the venture separately and in kind." In his Honour's view, the product of the joint venture was the copyright in the camera tapes. Whereas, for the majority Lindgren and Finkelstein JJ held that the parties owned the copyright in the tapes as tenants in common.

Ultimately, product includes profit so why should the different stage of conversion determine the structure $?^{70}$ Thompson $^{71}$ refers to early cases ${ }^{72}$ "which distinguished joint purchases of goods for resale jointly by adventurers which might give rise to partnership and joint purchase for division and separate sale by the individual adventurers which did not" as providing further support for this product sharing distinction. Hoare v Dawes ${ }^{73}$ and Grace v Smith ${ }^{74}$ were decided on the basis of whether or not there was a partnership and whether there was to be a sharing of the profit and loss. Generally the cases do not support the joint or separate product distinction. However,

65 Birtchnell v Equity Trustees Executors \& Agency Co (1929) 43 CLR 348, 407- 408, as stressed by Dixon J; the Court also referred to the remarks of James L.J in Re Agriculturist Cattle Insurance Co, Baird's Case (1870) L R 5 Ch App, 725, 732733.

66 (1985)157 CLR 1, 15

67 The Hon B H McPherson J, Suggested features of Joint Ventures in PD Finn (ed 1987), Equity and Commercial Relationships, Law Book Co, Sydney, 21.

68 (1828) 8 B \& C 612; 108 E R 1170.

69 (2005) 222 A L R 595, 569.

70 See M Chetwin, Joint Ventures - a branch of partnership law?, (1991) 16 U Q L J 256, 271.

71 N Thompson, The nature of the joint venture, in W D Duncan (ed), Joint Ventures Law in Australia, (2 ${ }^{\text {nd }}$ ed 2005), The Federation Press, Sydney, 33.

72 See Hoare v Dawes (1780) 1 Doug 371; Coope v Eyre (1788) 126 ER 24; Grace v Smith (1775) 2 Wm B1 998 ; 96 ER 587.

73 (1780) 1 Doug 371.

$74 \quad$ (1775) 2 Wm B1 998; 96 ER 587. 
the distinction is evident in the dissenting judgment of Wilson J in Coope $v$ Eyre ${ }^{75}$ in the discussion of evidence as to whether the contract was joint or separate. A better distinction may be that joint purchases of goods for resale jointly by adventurers might give rise to partnership and joint purchase for division and separate sale by the individual adventurers is a separate contract. ${ }^{76}$

In many joint ventures such as in the case of a property development, product taking is not possible. ${ }^{77} \mathrm{~A}$ more appropriate distinction was advanced in Spree Engineering and Testing Limited v O'Rourke Civil and Structural Engineering Limited ${ }^{78}$. The court distinguished between a partnership and a joint venture on the basis that a partner receives profit whereas, the joint venturer generally shares no more than gross payments. This covers joint venturers in a broader range of industries than the profit product distinction.

\section{CONCLUSIONS}

Joint ventures are a common arrangement in business. In specified industries, common characteristics can be stated but because of the broad range of joint ventures generally this is not the case. The authorities illustrate the differing views on this broad arrangement and reiterate the futility of defining or isolating the characteristics. The facts will be important to determine the structure involved. If it is an unincorporated joint venture, which is not a partnership, the contract must comply with the traditional essentials to be a binding contract. Contracts vary greatly and a definition of a joint venture is therefore inappropriate. All that can be stated is that the venturers are working in pursuit of a common object or a non-integrated project and this echoes the definition in United Dominions Corporation Ltd v Brian Pty Ltd ${ }^{79}$ where a joint venture was defined in ordinary language. However, the fact that the parties do not enter into a detailed formal agreement before embarking on their project does not mean that a party is not in a joint venture. The intentions of the parties and the substance of the arrangement are of prime importance. The recent New Zealand Supreme Court decisions have emphasised that in legal terms, there can be a joint venture and a venturer can be liable when the parties have not formed a contract. "The key point is not how, precisely the relationship is described, but rather whether the relationship between the parties was of a kind which gave rise to fiduciary duties on each side." ${ }^{\prime 80}$

75 (1788) 126 ER 24.

76 Elias CJ in Chirnside v Fay [2007] 1 NZLR 433, 442 noted the separate business and profit taking: The label joint venture may sometimes be used to describe what are in fact separate businesses operating at arm's length, with profits taken separately and directly by the participants instead of being realised by the venture itself (as is common in the case of mineral exploration or share-milking, for example). The Supreme Court held that Messrs Chirnside and Fay, who had not entered into a contract were joint venturers in a property development.

77 See Pursell $v$ Newberry (1967) 67 SR (NSW) 415, the Court of Appeal adopted the view, that an association of persons engaged in a common undertaking to produce a product which was shared by them in joint ownership constituted a joint venture in respect of the building of a boundary fence by adjoining landowners.

78 May 18, 1999 (NLC 299058403), this quote was cited in the Northern Ireland Court of Appeal decision, Sweeney v Lagan Developments Ltd [2007] NICA 11.

79 (1985) 157 CLR 1, 10 per Mason, Brennan and Deane JJ.

80 Per Blanchard J in Chirnside v Fay [2007] 1 NZLR 433, 458. 


\section{NOTES}

